DOI: 10.20472/EFC.2019.011.014

IRIDA VEJSIU

Societe Generale Albania Sh.a, Albania

\title{
THE ROLE OF RECRUITMENT IN THE FINANCIAL PERFORMANCE OF THE BANKING SYSTEM
}

\begin{abstract}
:
Among the HR processes, recruitment has been considered to be one of the most important ones. Many theories nowadays emphasize the importance of recruitment practices in the welfare of an organization, stressing that its impact is crucial even in the business financial performance.

The study has been focused on the impact of the recruitment practices in the financial results of 6 banks in the banking market in Albania! A deep analysis has been done, with the data gathered on the recruitment method for the involved banks, through the use of both SPSS and Econometric methods. The sources used for collecting the data has been both primary through surveys conducted and secondary through the information gathered from different online sources.

This study has been conducted to evaluate the impact of the selection method of two categories of employees, experienced once and the recently graduated, on the overall performance and financial results of the business.

The study is concluded with the analysis of the results showing a clear distinction on the costs of the business for recruitment of both categories, meaning that the recently graduated are less costly for the business. However there is not a clear distinction weather the recently graduates are performing better in comparison to the experienced recruited employees.
\end{abstract}

\section{Keywords:}

Recruitment, Banking, Recently graduated, Pre experienced, Business Performance

JEL Classification: G00, G20, M00 


\section{Introduction}

Human Resources are considered to be a very crucial factor for organizations; they are the key toward the development, growth and consolidation of businesses today, Hall (2003). Competition between companies in the market has become rigid. In order to beat the competition and be successful nowadays organizations have recognized that the key of their success is the human capital. Human capital is crucial, especially to the service provider companies, which constitute more than eighty percent of the total market worldwide, Krajewski et.al (2004). In this regard organizations need to pay major attention to the choice of their recruitment strategy. Successful recruitment leads the companies toward successful results.

"This increase in the importance of human resources has not happened accidentally". This is because of changes in the business environment. Considering the increased rate of the worldwide wealth, in order for companies to compete on the global environment, need to realize the importance of human capital. "Pressures from competitors, shareholders, and customers require that people create new products, services, and processes ahead of the competition" Brockbank (1999).

The above facts, enhance the significance the recruitment should have on the nowadays companies. From this point of view, it is crucial for companies to employ the right people that consequently will lead the organization toward the success. Hence, we were motivated in conducting a study in an area with such a major interest that is the human capital.

Linking recruitment strategies with the Banking System in Albania would be the purpose of the study, aiming this way to deeply analyse the impact of the strategy followed in recruiting their staff to such a competitive environment. Currently there are 15 banks operating in a small market, making them in the meantime among the biggest employers in the country.

This study aims to measure the hiring costs of the new employees in the banking system in Albania by measuring the new staff salary, performance bonus and other bonuses and benefits, the on boarding training costs and the training costs during the first year of employment in the institution.

Through the primary and secondary data received from some of the banks in the market would be able to directly calculate the costs associated with the recruitment in order then to test the hypothesis on the impact of the recruitment costs to the financial performance of the banking business in the country. 


\section{Literature Review}

\subsection{Recruitment and Selection}

Nowadays both scholarly books and popular business press have emphasized the importance of human resources management. Examples come from authors like Huselid (1995), MacDuffie (1995), Welbourne and Andrews (1996) that covered this study area on the scholarly researches. Fisher (1997) and Ulrich (1997) covered the human resources issues in the popular business press.

Human resources are considered to have significant importance on the companies' focal concerns such as return on assets and investments, profitability but also human resources effects even on the organizational survival. Taking into consideration this indispensable importance of human resources, recruitment is considered to have a major role in contributing in creating an effective human resources management. The major aim of recruitment is on drawing the most important source of a company that is the human capital. The success of other following procedures such as selection, training and compensations are dependent on the quantity and quality of the individuals that have been identified and attracted during the recruitment face Barber (1998).

Sherman et.al. (1998) defined recruitment as "a process of locating and encouraging potential applicants to apply for existing or anticipated job openings".

Another definition of the recruitment predict that "Recruitment is the process of searching for inducing prospective employees to apply for a job in the organization, with the purpose of increasing the selection ratio, that is, the number of applicants for job opening" Jain (1974).

Nowadays employers are facing problems such as concerning the choice of procedure in screening job applicants, the rate of hiring, training programs for new employees, etc Barron et. al. (1987).

Organizations now are more aware of the fact that the future of their business depends to a large extent on the quality of human resources. In this regard matching individuals with organization is important. Here the term matching refers to "the degree of congruence between relevant characteristics of the individual and the work organization, on the basis of which both parties decide by mutual consent to enter into a work relationship for a certain time" Boerlijst (1989).

There are two factors that assist in getting a "good fit" between individual and organization. The first factor concerns the establishment of a balance between individual abilities and required individual abilities from the company and the second between the "needs" of the individual and the "reinforcer system" of the organization. From the organization development point of view the main objective of matching is creating good condition that will support a continuous development of human resources competences 
within the company and secure future maintenance of these human capabilities for future company performance Boerlijst (1989).

\subsubsection{Graduate Employees}

The data shows that business management graduates are ranked the first in getting a chance to be employed in the field of their study. When it comes to the level of the starting salaries, they do not seem to appear among the professions that get the highest entry-level salaries Scheetz (996). Despite these facts other studies address the graduates issues in different perspectives, they emphasize that it is very important that employers understand in depth the first year experience of college graduate new employees. One of the reasons why this is important is that college graduates are considered to be a significant source of new employees for organizations. Companies that hire college graduates, base the decision on the long-term potential of college graduates to become future leaders. The first year of work experience for college graduates is critical and much more difficult compared to the pre-experienced new hires.

But some how they both face challenges that associate the first year of experience in a new organization Polach (2004).

On the other hand, Lois (1980) accentuates that regardless the fact that the new hires might be college graduates or pre-experienced any major role change concerns socialization within the new role and new settings. Furthermore the first year of experience is associated with disorientation, foreignness, and in the meantime it creates a kind of sensory overload for the new comers. For the college graduates the first year of experience is considered as dramatic. They face new situations such as moving to a new community, considerable income for the first time, establishing a home, or the concern to contribute and feel useful for the organization.

\subsubsection{Pre-experienced}

Some employers have preferences in hiring candidates with a previous experience especially when it comes to filling positions that require abundant knowledge and skills. Pre-experienced employees do not only have the privilege of getting a job easy, they also tend to get higher salaries compared to the college graduates new employees. Empirical evidence shows that there is a strong positive relation between experience and employee earnings, but in the meantime, there is no relation or exist a negative relation between experience and performance Medoff et. al. (1980). On the other hand Lois (1980) suggests that the major percentage of wage increase incurs within the first year of employment. Furthermore he argues that as graduates also pre-experienced new comers face the challenges of the socialization process within the new organization. These challenges are emphasized more when there is a considerable difference between the new and the old environment Altonji et.al (1987). 
Employees with more than average pre-company experience get higher than average salaries. This way there is a strong positive relation between pre-company experience and salaries. One of the explanations for the higher salaries of workers with pre-company experience is based on the fact that during their previous experience these workers gain valuable skills that will result in a better productivity compared to the less experienced employees. Human capital theory, provides another explanation, that is, through their work experience employees gain productivity-augmenting skills Medoff et.al. (1980).

\subsection{Costs of the new recruited employees}

Recent studies show that it is quite difficult to measure the hiring costs and measurement criteria might vary based on each organization, industry and country. The most common hiring costs can be : External Hiring team, Internal HR Team, Career Events, Job Board fees, Background checks, On boarding and training, Careers page, Salary + extras. Most of the studies accentuates that it is extremely difficult to measure the costs of hiring new employees.

The following table provides some hiring costs calculated from different associations and organizations.

Table 1: Cost of Hiring

\begin{tabular}{lccc}
\multicolumn{1}{c}{ Organization } & Hiring Costs & $\begin{array}{c}\text { Average Days to } \\
\text { fill in a position }\end{array}$ \\
\hline $\begin{array}{l}\text { National Association of } \\
\text { Colleges and Employers }\end{array}$ & $\$$ & 7,645 & \\
$\begin{array}{l}\text { Society for Human } \\
\text { Resources Management }\end{array}$ & $\$$ & 4,129 & 42 \\
Glassdoor & $\$$ & 4,000 & 52 \\
\hline
\end{tabular}

Source: Mile Zivkovic, The True Cost of Hiring and Employee in 2018 https://hundred5.com/blog/cost-of-hiring-an-employee

For the purpose of this study in the costs associated with the hiring have been included, the salary of the new employees plus the bonuses and other benefits, training for on boarding and the training during the first year of employment.

While the external hiring team are not considered due to the fact that it is not commonly used practice for the non-managerial positions in the banking system in Albania. The other mentioned associated costs such as different means of position announcements 
and background checks are not associated with costs in the local market. The cost of the internal HR team has not been able to identify for the purpose of this study.

\subsubsection{Trainings}

According to encyclopedya.labotlawtalk.com, Training is the teaching of vocational or practical and relates to specific useful skills. It forms the core of apprenticeship and provides the backbone of content at technical colleges or polytechnics. Today it is often referred to as professional development.

According to McGehee, cited by Ford (1997), the definition that dictionary provide for the training might be considered as relatively narrow and pertinent mostly to the processes that are involved in gaining proficiency in a specific skill or competence. He prioritise better the industrial training judging it as a much broader one, consisting in programs such as the induction of new workers, improvement of performance of experience workers, etc.

The term "training" within the organizational context is used in describing any effort that is initiated by the company to foster learning for its employees. The main reason that nowadays organizations train their employees is based on the fact that through trainings they aim to bring employees knowledge, skills and abilities to the level that is required to bring adequate performance. In choosing the training methods, it is important for companies taking into consideration which methods are appropriate in learning knowledge, skills and abilities Sherman et.al. 1998). In the case that the training material is mainly factual the training methods such as lectures will be considered as appropriate. On the other hand if the training consist of large behavioural components, methods like on-the-job training will be used Fowler (1995).

As above underlined companies provide different kind of trainings. The type of trainings provided to the non-managerial level employees include Sherman et.al. (1998):

- On-the-Job Training,

- Apprenticeship Training,

- Cooperative Training,

- Classroom Instruction,

- Programmed Instruction,

- Computer-Based Training

Although as above mentioned there are many different forms of trainings, either on-thejob or professional trainings, on-the-job training has captured more the attention of many authors nowadays.

On-the-job trainings, and indication of on-the-job trainings on the wage level 
On-the-job training is important especially for those employees that are in the beginning of a job Medoff (1980). Another perspective for on-the-job training came from Duncan and Hoffman (1979) and Brown (1983), they suggest that on-the-job training is an important factor in explaining wage growth.

Some studies suggest that workers pay part of their on-the-job training by accepting a lower starting wage, and they get a greater wage growth in return of the on-the-job training investment they made. Barron et.al (1989) found out from the empirical studies that approximately, it has been evaluated that a new worker spent 150 hours in on-thejob training for the first three months of employment. These data regards to the company new hires, both graduates and pre-experienced workers, the latter, most probably with some prior training. Furthermore, empirical results show that there is no major relationship between on-the-job training and starting wages. Result shows that there is a negative significant impact of the previous experience on the wage growth Barron et. al. (1989).

Goldstein cited by Chao (1997), considers that on-the-job training is part of the unstructured training. According to him, unstructured training is an informal on-the-job instruction where an experienced existing company employee provides work assistance and teaches the new employee. Informal training is considered to be the most popular training method in nowadays organizations. It is also estimated that informal training is three to six times more used compared to formal (professional) training held in organizations. Unstructured trainings can take different forms such as on-the-job training, and also the valuable information that can be secured through the interaction of the new employee with other company employees that might or might not be authorized by the organization to do so. Through these unstructured training forms the new employee secure the needed information regarding his/her own job, work unit and also the entire organization. This learning process for the new employee is considered as organizational socialization Chao (1997).

During the first months of employment on-the-job training has been considered as an important activity. The studies' results suggest that for a new hired employee the time spent on-the-job trainings during the first three months is approximately 30 percent of the time. Barron et.al. (1989) found that in fact positions which require higher trainings are not associated with lower starting wages. In the similar conclusion come also Parsons (1985), he underlines that the effect of the on-the-job training in the wage is not negative.

Empirical findings also suggest that there is a positive relationship between wage growth, productivity in the one side and on-the-job trainings in the other side Barron et.al. (1989). The results showed that the primary factor affecting wage and productivity is on-the-job training. The same conclusion concerning wage growth brought Brown (1983), Duncan and Hoffman (1979), and Mincer (1984). 


\subsubsection{Wages}

According to investordictionary.com A wage is the price paid for the use of services of labor per unit of time (per hour, per day, and so on). A wage is an amount of money paid to a worker for some specified quantity of labour. When expressed in respect of time, it is typically called the wage rate.

Any analyze or conclusion in regard to wages can be easily supplied if an understanding of the wage determination factors will be created.

There are internal and external factors that indicate in determining the employees wage level. Internal and external factors' interaction constitutes the wage mix Sherman et. al (1998).

There is a positive relation between experience and earnings. Empirical study comes to the conclusion that an additional year of pre-company experience beyond the average amount results some how in a small but also considerable positive increment on the employee earnings. On the other hand an additional year of experience within the company above the average amount assures for the employees approximately more than one percent increase in their earnings Medoff et. al. (1981).

Stigler (1962) argues that exist a strong empirical support in regard to the positive relationship among wage rates and employer size. Different authors like Rosen (1970), Haworth and Reuther (1978), Pugel (1980), Mellow (1982), and Garen (1985) came to the same conclusion in founding that larger employers pay higher wages.

\subsection{Performance}

In organizations people want to do a good work and achieve good results. In this case the empowering organizations improve their actions but in the meanwhile the constrained organizations hinder them. People in different organization doing the same things might have different roles. One key factor why this difference might appear is how the organizations focus on performance Foy (1994). The people, the employees, want to know and deserve to know two things: what they are supposed to do in the meaning what is their main task, what the organizations expect from them, and also feedback in form of comments and evaluation, which answer the employees' wonderings on: how am I doing? Lack of this feedback and tools to measure their performance can have the effect that the employees will start to measure the quality and quantity of absurd things, like how many and how long the tea breaks are. And even how many customers they can irritate, this just simply to reassure themselves that they really exist and be a part of the organization. The organization should try to avoid this situation to arise because the organization itself wins by giving people something more worthwhile to measure like their own performance. This will meet the needs of their own, their management and the organizations and creates win-win situations Foy (1994). 


\subsubsection{Business Performance}

Many studies nowadays emphasize that there is a strong relation of human resources policies and organizational performance. Most of the authors have been focused especially on the quality of the staff and recruitment practices and its impact on the performance of the business. Gamage (2014) and Sang (2005) on their studies have identified a strong relationship among the recruitment and selection and the performance of the company and this relationship is positive, meaning that the highest quality of the recruited employees the highest the level of organizational performance.

Djabatey (2012) reported that appropriate recruited candidates are critical for a company to build a competitive advantage. Furthermore on the competitive advantage of the companies and its sustainability Barney (1991) arguments that companies through the carefully selected human resources which are of high level of quality and difficult to be imitated by the competition, can create a competitive advantage.

Feuss Et.al (2004), in their study have developed An Emerging Theory of Business as in the following chart, where is clearly identified the relation among employee performance and organizational profitability.

\section{Figure 1: An Emerging Theory of Business}



\subsection{An Empirical Finding}

Johanson and Larsen (2000) conduct an empirical study aiming on comparing the costs of employing chartered accountants with the costs of employing newly graduate accountants for auditing companies in Sweden.

The empirical result suggests that in the case of auditing companies hiring a newly graduate accountant is more expensive than hiring a charter accountant. The difference in companies' costs for graduate and chartered accountant new employees can be explained due to the fact that graduate accountants need internal trainings. Although there is evaluated to be more costly for companies to hire graduate accountants, Johanson and Larsen (2000) argue that this does not guarantee the right answer concerning the recruitment strategy company should opt for. Furthermore, they argument 
that if only the cost factor would be taken into consideration, only chartered accountants would be recruited by companies and all the internal trainings will be close down. In case other companies will do the same, than they will also close down internal trainings. As a result it will be more difficult for companies to recruit charter accountants and in the meantime headhunting costs will increase. Johanson and Larsen (2000) also found out that internal training might be considered as a contributing factor in employees' loyalty toward company, which in a long-term perspective will result on a reduction of personnel turnover.

\subsection{Summary of the Theory}

Based on the revision of the literature, we have created the model of our study as shown in Fig. 3. In the center of the study is recruitment as a core process for the business which can impact both the costs and the performance of the business. Hiring of which of the two categories, i.e. graduates or pre-experienced, can be the most appropriate choice of the companies?

\section{Figure 2: Model of the Study}



Source: Own Judgement

\section{Methodology}

\subsection{Collection of Data}

The data from six banks out of 16 in total operating in the Albanian Banking Market have been collected both from the primary and secondary sources. For the primary sources have been used the surveys completed from the directors of the human resources department of the involved banks. The questioners has been built with a total of 19 questions which have been both open ended and closed questions. The data has been gathered from the last three years, i.e. 2015, 2016 and 2017 for the staff recruited in these banks, aiming this way to provide more consistent results.

The secondary data has been gathered using mostly the website of the Albanian Association of Banks, which has provided mostly statistical data needed for the study such as the financial performance in the baking system and of the banks that have participated in the study. 
Due to the criticality of the data, most of the banks that participated in the survey asked to remain anonymous. In such regard in the study are not used the real names of the banks.

The data collected for the study has been processed using the statistical program such as SPSS.

For the purpose of the study the data collected via the surveys have been categorized by the positions of the staff hired for the two groups, i.e recently graduated and pre experienced employees. All the staff involved in the sales functions have been categorized as customer service positions, all the staff involved in the functions supporting the sales employees, have been categorized support functions junior and senior and all the staff that based on the hierarchy have employees under supervision are categorized as managerial positions.

Costs are calculated in the local currency, Albanian Lek (ALL). ${ }^{1}$

\section{Empirical Results}

\subsection{Banking System in Albania}

As of 2018 data, the banking system in Albania operates with a total no. of 16 banks, local and international ones and with a total no. of staff 6,878 employees, making banking system among the biggest employers in Albania. The competition in the banking system is fierce considering the big no. of banks for a small market such as Albania. There is strong competition both in terms of customer generations and staff gain. In such regard the banks invests a lot in terms of human resources management in order to create $e$ good work environment for the staff.

There are two major categories of staff working in the banking system, the sales staff and the support functions, who support the work of the sales employees.

For the purpose of the study are taken into account the data from six banks operating in the market.

The net profit in the banking system has been volatile, with ups and downs during the years, reaching the max net profit during 2011 and the min one during 2016.

${ }^{1}$ Exchange rate $1 \mathrm{USD}=109.2 \mathrm{ALL}$,

https://www.bankofalbania.org/Tregjet/Kursi zyrtar i kembimit/05.02.2019,15:34 


\section{Figure 3: Net Profit in the Banking System}

\section{Net Profit of the banking system 2005-2017}

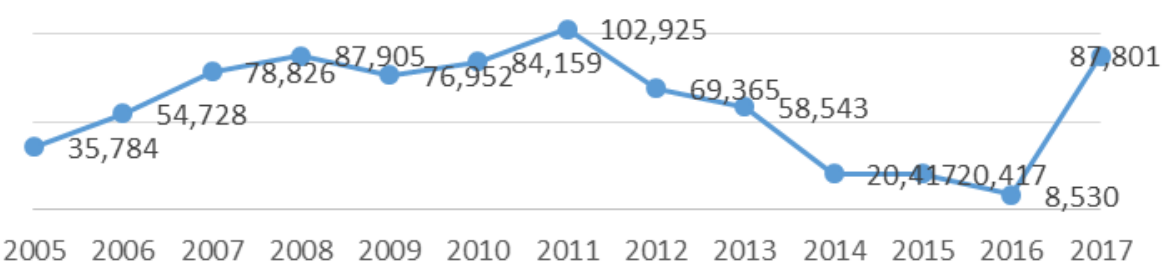

Source: Albanian Association of Banks statistics 2005-2017

The figures related to the net profit have been volatile for the banks involved in the study as well, where the max profit has been reached during 2011 and the min one during 2014. However for Bank $F$ the situation has been very stable during the years, while for the other five banks there have been ups and downs in terms of net profit. The most profitable one over the years is the bank green lined in the graph, Bank I. Many factors might have impacted their net profit over the years. One of them might be considered also their recruitment strategy and their investments toward the staff development.

\section{Figure 4: Net Profit Banks under the Study}

\section{Net Profit of the Banks 2005-2017}



Source: Albanian Association of Banks statistics 2005-2017

While analysis of the net profits in the banks will be followed by some analysis in terms of the staff working in the banking system during the timeframe.

The banking system in terms of staff has been very stable during the last years with no major changes, increases or decreases. The major increase in terms of the staff no. has 
been during the period 2005 to 2008 . Followed afterwards by a period a stability in terms of staff data.

Figure 5: No. of Employees in the Banking System

No of the employees in the banking system 2005-2017

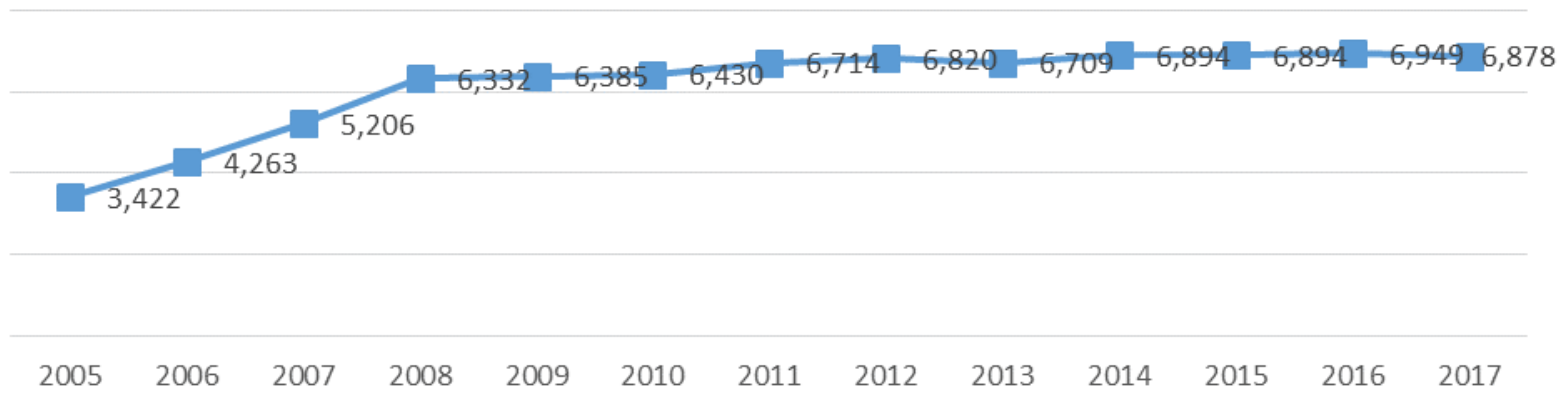

Source: Albanian Association of Banks statistics 2005-2017

Almost the same trend has been preserved even for the six banks of the study, except Bank $\mathrm{C}$ for which the increasing trend has continued over the years and has reached its peak during 2017.

Figure 6: No. of Employees for the involved banks

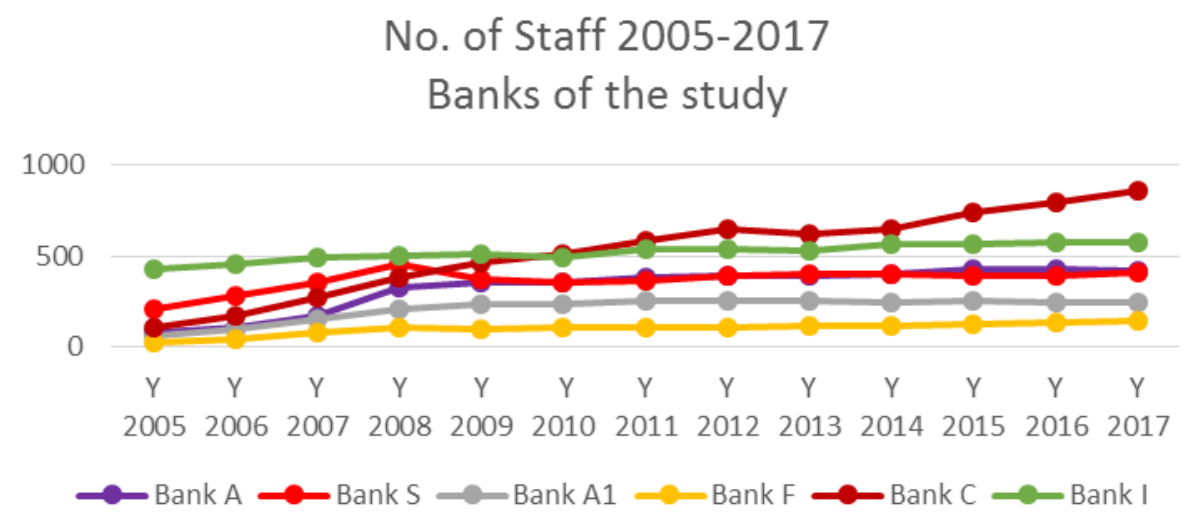

Source: Albanian Association of Banks statistics 2005-2017

\subsection{Recruitment}

The six banks taken into consideration for the study have a total no. of 2720 employees as of the end of 2017, representing $38.5 \%$ of the banking system workforce. For the six banks the data on recruitment over the last three years demonstrate that they have a tendency to employee more new employees with prior experience than recently 
graduates. With an exception for the case of Bank $\mathrm{C}$, which seems to be more prone to the employment of the recently graduates.

Table 2: Staff recruited for the Six Banks

\begin{tabular}{|c|c|c|c|c|c|c|c|c|c|c|c|c|c|c|c|c|c|}
\hline & \multicolumn{3}{|c|}{ Bank I } & \multicolumn{3}{|c|}{ Bank S } & \multicolumn{3}{|c|}{ Bank F } & \multicolumn{3}{|c|}{ Bank C } & \multicolumn{2}{|c|}{ Bank A } & \multicolumn{3}{|c|}{ Bank A1 } \\
\hline & 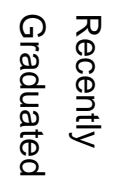 & 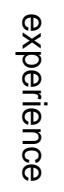 & $\underset{ほ}{\xi}$ & 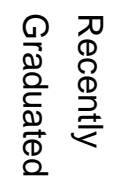 & 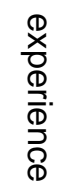 & $\sum_{\equiv}$ &  & $\begin{array}{l}\mathbb{D} \\
\frac{x}{0} \\
\mathbb{D} \\
\bar{D} \\
\bar{D} \\
\bar{D} \\
\mathbb{D}\end{array}$ & $\sum_{\equiv}$ & 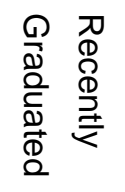 & 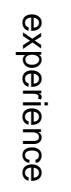 & $\sum_{\ddagger}$ & 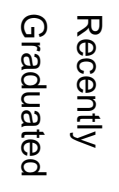 &  &  & $\begin{array}{l}\mathbb{D} \\
\frac{x}{0} \\
\frac{\Phi}{D} \\
\bar{\Phi} \\
\frac{\Phi}{D} \\
\mathbb{D}\end{array}$ & $\varliminf_{\Xi}$ \\
\hline \multicolumn{18}{|l|}{ Year } \\
\hline 2015 & 27 & & 31 & 22 & & 26 & 8 & & 17 & 73 & & 73 & 6 & 49 & 6 & & 28 \\
\hline \multicolumn{18}{|l|}{ Year } \\
\hline 2016 & 38 & & 47 & 15 & & 42 & 5 & & 21 & 82 & & 46 & 9 & 31 & 6 & & 34 \\
\hline \multicolumn{18}{|l|}{ Year } \\
\hline 2017 & 34 & & 45 & 18 & & 26 & 8 & & 12 & 77 & & 46 & 7 & 48 & 13 & & 39 \\
\hline
\end{tabular}

Source: Own adjustment based on the Questionary Results

Total No. of Staff for the six banks under the study are presented in the following table: Recruitment represent an important element for the banks considering the fact that in each year the ratio of recruitment over the total staff no. has an average of $13.71 \%$. Not to consider bank 4 for which the recruitment ratio goes to a level of $21.31 \%$.

Table 3: Total No. of Staff Vs. Recruitment

\begin{tabular}{ccccc} 
No & BANKS & $\begin{array}{c}\text { No. of } \\
\text { Employees } \\
2017\end{array}$ & $\begin{array}{c}\text { Recruitment } \\
2017\end{array}$ & $\begin{array}{c}\text { Recruitment in } \\
\% \text { of total staff }\end{array}$ \\
\hline 1 & Bank A & 414 & 55 & $13.29 \%$ \\
2 & Bank A1 & 244 & 52 & $21.31 \%$ \\
3 & Bank C & 881 & 123 & $13.96 \%$ \\
4 & Bank F & 180 & 20 & $11.11 \%$ \\
5 & Bank I & 582 & 79 & $13.57 \%$ \\
6 & Bank S & 419 & 44 & $10.50 \%$ \\
\hline & TOTAL & 2,720 & 373 & $13.71 \%$
\end{tabular}

Source: Albanian Association of Banks- Statistics 
Taking into consideration the fact that over the last three years, for the six banks under the study the total stuff no. has remained stable, a recruitment rate average of $13.71 \%$ means that close to this figure is also the turnover rate on a yearly bases. This means that for a period of five years more than half of the bank staff has left and substituted with the new recruited employees. This process in itself might be costly and has its impact in the bank overall financial results as well.

\subsection{Total Expenses}

The data collected from the surveys for the calculations of the costs on the recruitment of new employees are related to the wages, training expenses and bonuses plus extras.

\subsubsection{Wage Expenses}

The data evidenced from the study for the six banks clearly identify that the employees recruited with an experience in a required filed are getting higher salaries on all the positions they are getting hired. In the banks of the study there is no managerial positions filled with candidates which are recently graduated. The sales functions get higher wages than the junior support functions, while the senior support functions are better paid in terms of wages compared to the sales functions.

\subsubsection{Training Expenses}

When it comes to the training expenses are considered three categories of training, the on boarding, training within the first year of employment and on the job training. Based on the data received from the banks it results that these costs are higher for the employees with experience when it comes to the induction training and training received within the first year of employment, while these data are reversed somehow when it comes to the on the job training.

\subsubsection{Bonuses and other Benefits Expenses}

Bonuses paid for the pre-experienced employees are higher in most of the cases, taking into consideration their wages as well.

The total expenses are calculated taking into consideration the wage of the first month plus all the training expenses, bonuses and other benefits within the first year of the position. If we take into consideration that the institution bare other costs such as taxes and benefits paid on behalf of the employee by the bank, the total calculated costs might be much higher for the new entries. 


\section{Figure 7: Total Expenses per Category}

Total Expences per category

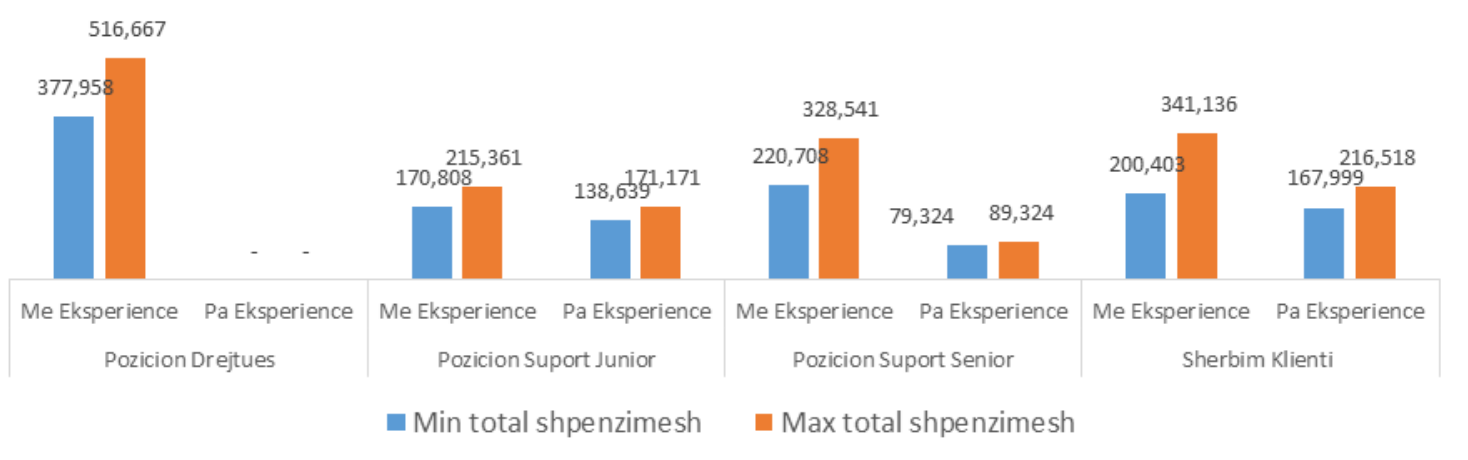

Source: Own adjustements based on the questionary data

From the analysis of the data gathered it has been very difficult to demonstrate a clear relation among the experience of the recruited employees and their performance. In the meantime it is clearly represented in the data that recruitment of an employee in the organization is costly. The major costs are coming from the employees with prior experience.

\subsection{The empirical model}

Our aim was to calculate the impact of the recruitment on on the financial performance of the business.

In order to understand the impact of the recruitment on the financial impact of a banking institution in Albania, was build the following regression model to test the hypothesis:

$Y=a 0+a 1 X 1+a 2 X 2+a 3 X 3$

Where independent variables are:

$\mathrm{X} 1=$ Wage costs for the new recruitments

$\mathrm{X} 2=$ Training Costs for the new recruitments

$\mathrm{X} 3=$ Cost of bonuses and other benefits for the new recruitments

And Dependent variable is:

$Y=$ Financial performance of the business 
This way we aim to test the impact of the recruitment costs on the financial performance of the business. The hypothesis of the theoretical model are as follows:

$\mathrm{H} 0: \mathrm{a} 1=\mathrm{a} 2=\mathrm{a} 3=0$

$\mathrm{Ha}$ : At least one of the variables is different than 0 .

\section{$5 \quad$ Results}

\section{Table 4: Model Summary Year 2015}

\section{Model Summary}

\begin{tabular}{|l|r|r|r|r|}
\hline Model & \multicolumn{1}{|c|}{$\mathrm{R}$} & R Square & \multicolumn{1}{|c|}{$\begin{array}{c}\text { Adjusted R } \\
\text { Square }\end{array}$} & $\begin{array}{c}\text { Std. Error of } \\
\text { the Estimate }\end{array}$ \\
\hline 1 & $.795^{\mathrm{a}}$ & .632 & .495 & 4571.89790 \\
\hline
\end{tabular}

a. Predictors: (Constant), MinTrajnim_sum, MinBonus per performance viti I pare mesatare, MinPagaMujore

R- Represent the multi coefficient of the correlation, $R$ can be considered as a measurement of the quality of the dependent variable, in our case of the financial performance of the institutions taken into consideration for the purpose of the study. A value of 0.795 , in this analysis, relates to a good level of forecast. $R 2=0.632$ indicates that the independent variables have an impact of $63.2 \%$ on the dependent variable, i.e. financial performance of the banking institutions considered for the study.

Table 5: ANOVA Year 2015

\begin{tabular}{|c|c|c|c|c|c|c|}
\hline \multicolumn{7}{|c|}{ ANOVA $^{a}$} \\
\hline Model & & Sum of Squares & $d f$ & Mean Square & $\mathrm{F}$ & Sig. \\
\hline \multirow{3}{*}{1} & Regression & 287671901.197 & 3 & 95890633.732 & 4.588 & $.038^{b}$ \\
\hline & Residual & 167218003.053 & 8 & 20902250.382 & & \\
\hline & Total & 454889904.250 & 11 & & & \\
\hline
\end{tabular}

a. Dependent Variable: Performance 2015

b. Predictors: (Constant), MinTraining_sum, MinBonus on performance $1^{\text {st }}$ year average, Min Monthly salary

$F$ in the ANOVA table - prove the importance of the statistical model. From the data in ANOVA table comes clear that the statistical model forecast to a great extent the dependable variable $(3,9)=4.588, p<0005$ meaning that there might be a 
mathematical link explaining the performance of the companies taken into consideration the costs of salary, training, bonuses and other benefits of the new recruitments.

For the statistical importance we take into consideration the $t$ values and Sig. (significance) on the following table. The variables with a significance smaller than 0.05 are statistically important. In such regard as preserved in the following table the costs of the wages and the training costs are considered important on the financial performance for the five banks considered for the study.

Table 6: Coefficients Year 2015

\begin{tabular}{|c|c|c|c|c|c|c|}
\hline \multicolumn{7}{|c|}{ Coefficients $^{a}$} \\
\hline \multirow[t]{2}{*}{ Moc } & & \multicolumn{2}{|c|}{ Unstandardized Coefficients } & \multirow{2}{*}{$\begin{array}{c}\text { Standardized } \\
\text { Coefficients } \\
\text { Beta }\end{array}$} & \multirow[t]{2}{*}{$\mathrm{t}$} & \multirow[t]{2}{*}{ Sig. } \\
\hline & & $\mathrm{B}$ & Std. Error & & & \\
\hline \multirow{5}{*}{1} & (Constant) & 4311.819 & 2635.250 & & 1.636 & .140 \\
\hline & MinMonthySalary & .013 & .005 & .653 & 2.658 & .029 \\
\hline & MinBonus on & & & & & \\
\hline & $\begin{array}{l}\text { performance } 1^{\text {st }} \text { Year } \\
\text { average }\end{array}$ & .002 & .003 & .198 & .828 & .432 \\
\hline & MinTraining_sum & -.003 & .001 & -.745 & -3.110 & .014 \\
\hline
\end{tabular}

a. Dependent Variable: Performance 2015

We can built this way the following equation:

Financial Performance $=4311.819+0.013^{*}$ MinMonthlySalary $+0.002^{*}$ MinBonus $-0.003^{*}$ MinTrainingSum

The above equations means that for an increase on one of the monthly salary for the new hires there would an increase of the financial performance of the business of 0.0013 .

While for an increase of one of the training costs for the new hires there would be a decrease on the financial performance of the business.

As a conclusion the regression on the impact of the costs of salary, training, bonuses and other benefits on the financial performance of the business is statistically important, $F$ ( $3,(), p<.0005, R 2=.632$. Two variables resulted statistically important on the business performance with $\mathrm{p}<.05$.

\section{Year 2016}

For the data related to the year 2016 the following statistical models have been built. 


\section{Table 7: Model Summary Year 2016}

Model Summary

\begin{tabular}{|l|r|r|r|r|}
\hline Model & \multicolumn{1}{|c|}{$\mathrm{R}$} & $\mathrm{R}$ Square & $\begin{array}{c}\text { Adjusted R } \\
\text { Square }\end{array}$ & $\begin{array}{c}\text { Std. Error of } \\
\text { the Estimate }\end{array}$ \\
\hline 1 & $.811^{\mathrm{a}}$ & .657 & .528 & 3724.44109 \\
\hline
\end{tabular}

a. Predictors: (Constant), MinTrajnim_sum, MinBonus per performance viti I pare mesatare, MinPaga Mujore

A value of 0.811 , in this analysis, relates to a good level of forecast. $R 2=0.657$ indicates that the independent variables have an impact of $65.7 \%$ on the dependent variable, i.e. financial performance of the banking institutions considered for the study.

\section{Table 8: ANOVA Year 2016}

ANOVA $^{a}$

\begin{tabular}{|c|c|c|c|c|c|c|}
\hline \multicolumn{2}{|c|}{ Model } & Sum of Squares & $d f$ & Mean Square & $\mathrm{F}$ & Sig. \\
\hline \multirow{3}{*}{1} & Regression & 212644143.327 & 3 & 70881381.109 & 5.110 & $.029 \mathrm{~b}$ \\
\hline & Residual & 110971691.340 & 8 & 13871461.417 & & \\
\hline & Total & 323615834.667 & 11 & & & \\
\hline
\end{tabular}

a. Dependent Variable: Performanca 2016

b. Predictors: (Constant), MinTrajnim_sum, MinBonus per performance viti I pare mesatare, MinPaga Mujore

$F$ in the ANOVA table - prove the importance of the statistical model. From the data in ANOVA table comes clear that the statistical model forecast to a great extent the dependable variable $\quad(3,7)=5.110, p<.0005$ meaning that there might be a mathematical link explaining the performance of the companies taken into consideration the costs of salary, training, bonuses and other benefits of the new recruitments.

For the statistical importance we take into consideration the $t$ values and Sig. (significance) on the following table. The variables with a significance smaller than 0.05 are statistically important. In such regard as preserved in the following table the costs of the min bonus the first year of employment and the training costs are considered important on the financial performance for the six banks considered for the study. 
Table 9: Coefficients Year 2016

Coefficients $^{\mathrm{a}}$

\begin{tabular}{|c|c|c|c|c|c|c|}
\hline \multirow[t]{2}{*}{ Mod } & & \multicolumn{2}{|c|}{ Unstandardized Coefficients } & \multirow{2}{*}{$\begin{array}{c}\text { Standardized } \\
\text { Coefficients }\end{array}$} & \multirow[t]{2}{*}{$t$} & \multirow[t]{2}{*}{ Sig. } \\
\hline & & $\mathrm{B}$ & Std. Error & & & \\
\hline \multirow{5}{*}{1} & (Constant) & 7762.938 & 2146.775 & & 3.616 & .007 \\
\hline & MinPaga Mujore & .000 & .004 & -.010 & -.041 & .968 \\
\hline & MinBonus per & & & & & \\
\hline & $\begin{array}{l}\text { performance viti I pare } \\
\text { mesatare }\end{array}$ & .007 & .002 & .705 & 3.057 & .016 \\
\hline & MinTrajnim_sum & -.002 & .001 & -.701 & -3.032 & .016 \\
\hline
\end{tabular}

a. Dependent Variable: Performanca 2016

We can built this way the following equation:

Financial Performance $=7762.938+0.000^{*}$ MinMonthlySalary $+0.007^{*}$ MinBonus $-0.002^{*}$ MinTrainingSum

The above equations means that for an increase on one of the bonus for the new hires there would an increase of the financial performance of the business of 0.007 .

While for an increase of one of the training costs for the new hires there would be a decrease on the financial performance of the business.

As a conclusion the regression on the impact of the costs of salary, training, bonuses and other benefits on the financial performance of the business is statistically important , F( $3,(), p<.0005, R 2=.657$. Two variables resulted statistically important on the business performance with $\mathrm{p}<.05$.

\section{Year 2017}

Table 10: Model Summary Year 2017

Model Summary

\begin{tabular}{|l|r|r|r|r|}
\hline Model & $\mathrm{R}$ & R Square & \multicolumn{1}{|c|}{$\begin{array}{c}\text { Adjusted R } \\
\text { Square }\end{array}$} & $\begin{array}{c}\text { Std. Error of } \\
\text { the Estimate }\end{array}$ \\
\hline 1 & $.835^{\mathrm{a}}$ & .698 & .584 & 2214.08481 \\
\hline
\end{tabular}

a. Predictors: (Constant), MinTrajnim_sum, MinBonus per performance viti I pare mesatare, MinPaga Mujore 
A value of 0.835 , in this analysis, relates to a good level of forecast. $R 2=0.698$ indicates that the independent variables have an impact of $69.8 \%$ on the dependent variable, i.e. financial performance of the banking institutions considered for the study.

Table 11: ANOVA Year 2017

ANOVA $^{\mathrm{a}}$

\begin{tabular}{|rl|r|r|r|c|c|}
\hline \multicolumn{1}{|l|}{ Model } & Sum of Squares & \multicolumn{1}{c|}{ df } & Mean Square & F & \multicolumn{1}{c|}{ Sig. } \\
\hline \multirow{4}{*}{1} & Regression & 90483657.344 & 3 & 30161219.115 & 6.153 & $.018^{\mathrm{b}}$ \\
& Residual & 39217372.322 & 8 & 4902171.540 & & \\
\cline { 3 - 4 } & Total & 129701029.667 & 11 & & & \\
\hline
\end{tabular}

a. Dependent Variable: Performanca 2017

b. Predictors: (Constant), MinTrajnim_sum, MinBonus per performance viti I pare mesatare, MinPaga Mujore

$F$ in the ANOVA table - prove the importance of the statistical model. From the data in ANOVA table comes clear that the statistical model forecast to a great extent the dependable variable $\quad(3,3)=6.153, p<.0005$ meaning that there might be a mathematical link explaining the performance of the companies taken into consideration the costs of salary, training, bonuses and other benefits of the new recruitments.

For the statistical importance we take into consideration the $t$ values and Sig. (significance) on the following table. The variables with a significance smaller than 0.05 are statistically important. In such regard as preserved in the following table the costs of the bonus the first year of employment and the training costs are considered important on the financial performance for the six banks considered for the study.

\section{Table 12: Coefficients Year 2017}

\section{Coefficients $^{\mathrm{a}}$}

\begin{tabular}{|c|c|c|c|c|c|c|}
\hline \multirow[t]{2}{*}{ Mod } & & \multicolumn{2}{|c|}{ Unstandardized Coefficients } & \multirow{2}{*}{$\begin{array}{c}\text { Standardized } \\
\text { Coefficients } \\
\text { Beta } \\
\end{array}$} & \multirow[t]{2}{*}{$\mathrm{t}$} & \multirow[t]{2}{*}{ Sig. } \\
\hline & & $\mathrm{B}$ & Std. Error & & & \\
\hline \multirow{5}{*}{1} & (Constant) & 6833.980 & 1276.202 & & 5.355 & .001 \\
\hline & MinPaga Mujore & -.001 & .002 & -.066 & -.294 & .776 \\
\hline & MinBonus per & & & & & \\
\hline & $\begin{array}{l}\text { performance viti I pare } \\
\text { mesatare }\end{array}$ & .005 & .001 & .750 & 3.462 & .009 \\
\hline & MinTrajnim_sum & -.001 & .000 & -.695 & -3.202 & .013 \\
\hline
\end{tabular}

a. Dependent Variable: Performanca 2017 
We can built this way the following equation:

Financial Performance $=6833.980-0.001^{*}$ MinMonthlySalary $+0.005^{*}$ MinBonus $-0.001^{*}$ MinTrainingSum

The above equations means that for an increase on one of the bonus for the new hires there would an increase of the financial performance of the business of 0.005 .

While for an increase of one of the training costs for the new hires there would be a decrease on the financial performance of the business.

As a conclusion the regression on the impact of the costs of salary, training, bonuses and other benefits on the financial performance of the business is statistically important, $F($ $3,(), p<.0005, R 2=.657$. Two variables resulted statistically important on the business performance with $\mathrm{p}<.05$.

\section{Analysis and Concluding remarks}

Banks under the study have the tendency to employee more pre experienced employees while the hiring costs for the pre experienced staff are higher than the ones for the recently graduated employees. From the data collected from the surveys has been difficult to assess whether these tendency of the banks to employee more employees with a previous experience is associated with a better performance of these category.

The hiring costs based on the data received, reach a max value for the Albanian Banking market of 4.731 \$ for the managerial positions and a min value of $726 \$$ corresponding to a junior support position. While the average recruitment expenses are calculated at a value of 2.289 \$. Considering the market average salaries in Albania which are lower in comparison with EU and other developed countries, the average recruitment costs calculated for the banking system in Albania can be somehow comparable with the hiring costs calculated by Glassdoor and the Society of Human Resources Management.

The hired employees with an experience have higher costs for almost all the categories of expenses considered for the study, except for the expenses related to on the job training. For the on the job training higher expenses are made for the recently graduated new employees. Medoff et. al. (1980) has emphasized that On-the-job training is important especially for those employees that are in the beginning of a job.

The hypothesis on the impact of the recruitment costs on the performance of the business has resulted with a significance, while when tested separately for the two categories of new employees pre experienced or recently graduated it has not resulted of statistical significance.

In such regard we can easily draw the conclusion that the costs of recruitment have impact on the performance of the business. Meaning that despite the importance that 
recruitment of the staff has for the company its associated costs are of a great impact on the financial results of the company as well. In such perspective we can draw the conclusion that for the six banks participated in the study, the staff hiring is of curtail importance not only for the quality of the service they provide in their positions but also for their associated costs which as tested in the hypothesis they have impact in the business financial results as well.

\section{References}

Altonji, G. J., \& Shakotko, A.R. (1987). Do Wages Rise with Job Seniority?, Review of Economic Studies, 54(179), pp. 437-59.

Barney J.B. (1991). Firm resources and sustained competitive advantage. Journal of Management, 17 (1), pp. 99-120. In Ekwoaba O. J., Ikeije U. U., Ufoma N. (2015) The Impact of Recruitment and Selection Criteria on Organizational Performance. Global Journal of Human Resources Management, Vol. 3, No. 2, pp. 23.

Barber (Eds.), Recruiting Employees: Individual and organizational Perspectives 1998, Sage Publications, Inc. USA, p. 1.

Barber, E. A. (1998). Recruiting Employees: Individual and organizational Perspectives, Sage Publications, Inc. USA, p. 1.

Barron, M.J., Black, A.D., \& Loewenstein, A.M. (1987). Employer Size: The Implications for Search, Training, Capital Investment, Starting Wages, and Wage Growth, Journal of Labor Economics, 5(1), p. 78.

Boerlijst, G., \& Meijboom, G. (1989). Matching the individual and the Organization. In P. Herriot (Eds), Assessment and Selection in Organizations: Methods and Practice for Recruitment and Appraisal 1989, John Wiley \& Sons Ltd., UK, pp. 25-32.

Brown, J. (1983). Are those Paid More Really No More Productive? In J.M. Barron, D. A. Black, \& M.A. Loewenstein, Job Matching and On-the-Job Training, Journal of Labor Economics, 1989, 7(1), p. 10.

Barron, M.J., Black, A.D., \& Loewenstein, A.M. (1989). Job Matching and On-the-Job Training, p. 1-19.

Barron, M.J., Black, A.D., \& Loewenstein, A.M. (1989). Job Matching and On-the-Job Training, Journal of Labor Economics, 7(1), pp. 1-19.

Barron, M.J., Black, A.D., \& Loewenstein, A.M. (1989). Job Matching and On-the-Job Training, p. 16.

Brockbank, W. (1999). If $H R$ were really strategically proactive: Present and future directions in $H R$ 's contribution, Human Resource management, 38(4), p. 337.

Brown, J. (1983). Are Those Paid More Really No More Productive? In J.M. Barron, D. A. Black, \& M.A. Loewenstein, Job Matching and On-the-Job Training, Journal of Labor Economics, 1989, 7(1), p. 16.

Chao G.T. (1997). Unstructured Training and Development: The Role of Organizational Socialization. In J. K. Ford, S. W. J. Kozlowski, K. Kraiger, E. Salas, \& M. S. Teachout (Eds.), Improving Training Effectiveness in Work Organizations 1997, Lawrence Erlbaum Associates, Inc., USA, p. 129.

Chao, T. G. (1997). Unstructured Training and Development: The Role of Organizational Socialization. p. 130. 
Djabatey E. N. ( 2012). Recruitment and selection practices of organizations: A case study of HFC Bank (GH) Ltd. Unpublished thesis submitted to the Institute of Distance Learning, Kwame Nkrumah University of Science and Technology. Ghana: Kwame Nkrumah University of Science and Technology. In Ekwoaba O. J., Ikeije U. U., Ufoma N. (2015) The Impact of Recruitment and Selection Criteria on Organizational Performance. Global Journal of Human Resources Management, Vol. 3, No. 2, pp. 23.

Duncan, G.J., \& Hoffman, S. (1979). On-the-job Training and Earnings Differences by Race and Sex, Review of Economics and Statistics, 61(4), pp. 593-603

Feuss J. W., Harmon J., Wirtenberg J., Wides J. (2004). Linking employees, customers, and financial performance in organizations. The Journal of Cost Management Vol 18, Nr. 1. pp. 20.

Fisher, A. (1997). The world's Most Admired Companies. In A.E. Barber (Eds.), Recruiting Employees: Individual and organizational Perspectives 1998, Sage Publications, Inc. USA, p. 1.

Ford J. K., (1997). Advances in Training Research and Practice: An Historical Perspective. In J. K. Ford, S. W. J. Kozlowski, K. Kraiger, E. Salas, \& M. S. Teachout (Eds.), Improving Training Effectiveness in Work Organizations 1997, Lawrence Erlbaum Associates, Inc., USA, p. 3.

Fowler, A. (1995). How to: Decide on Training Methods, People Management, 1(25), pp. 36-7.

Foy, N. (1994). Empowering people at work, Gower, Hampshire, England, p. 11.

Gamage A.S. (2014). Recruitment and Selection Practices in manufacturing SMEs in Japan: An analysis of the link with business performance. Ruhuna Journal of Management and Finance, 1(1), 37-52. In Ekwoaba O. J., Ikeije U. U., Ufoma N. (2015) The Impact of Recruitment and Selection Criteria on Organizational Performance. Global Journal of Human Resources Management, Vol. 3, No. 2, pp. 23.

Garen, E. J. (1985). Worker Heterogeneity, Job Screening, and Firm Size, Journal of Political Economy, 93(4), pp. 715-39.

Hall, S. (2003). HR Has Integral Part to Play in Business, Personnel Today, p. 15.

Haworth, Ch. T., \& Reuther, C.J. (1978). Industrial Concentration and Interindustry Wage Determination, Review of Economics and Statistics, 60(1), pp. 85-95.

Huselid, M.A. (1995). The Impact of Human Resource Management Practices on Turnover, Productivity, and Corporate Financial Performance, Academy of Management Journal, 38(3), pp. 635-72.

Jain, H. C. (1974). Managerial Recruitment and Selection in the Canadian Manufacturing Industry, Public Personal Management, 3(3), p. 207.

Johanson, U., \& Larsen, H.H. (2000). Human Resource Costing and Accounting: Putting a price on Human Resource Investment. In C. Brewster, \& H. H. Larsen, Human Resource Management In Northern Europe: Trends, Dilemmas and Strategy 2000, Blackwell Publishers Ltd, UK, p. 177-178.

Krajewski, J.L. \& Ritzman, P.L. (2004). Operation management: Processes and Value Chains, Pearson Prentice Hall, USA, seventh edn, p. 6.

Lois, M. R. (1980), Surprise and Sense Making: What Newcomers Experience in Entering Unfamiliar Organizational Settings, Administrative Science Quarterly, 25(2), pp. 226-49.

MacDuffie, J.P. (1995). Human Resource Bundles and Manufacturing Performance,: Organization Logic and Flexible Production Systems in the World Auto Industry, Industrial and Labor Relations Review, 48(2), pp. 197-221. 
Medoff, L.J., \& Abraham, G.K. (1980). Experience, Performance, and Earnings, Quarterly Journal of Economics, 95(4), pp. 703-36.

Medoff, L.J., \& Abraham, G.K. (1980). Experience, Performance, and Earnings, pp. 703-36.

Medoff, L.J., Abraham, G.K. (1981). Are Those Paid More Really More Productive?, The Case of Experience, The Journal of Human Resources, 16(2), pp. 186-216.

Mellow, W. (1982). Employer Size and Wages, Review of Economics and Statistics, 64(3), pp. 495-501.

Mincer, J.(1984). Labor Mobility, Wages, and Job Training, Mimeographed, New York: Columbia University. In J.M. Barron, D. A. Black, \& M.A. Loewenstein, Job Matching and On-the-Job Training, Journal of Labor Economics, 1989, 7(1), p. 16.

Parsons, D.A. (1985). Wage determination in the Post-schooling Period: The market for On the-Job training. In J.M. Barron, D. A. Black, \& M.A. Loewenstein, Job Matching and On-the-Job Training, Journal of Labor Economics, 1989, 7(1), pp. 15-6.

Polach, L.J. (2004). Understanding the Experience of College Graduates During Their First Year of Employment, Human Resources Development Quarterly, 15(1), pp. 6-7.

Pugel, Th. A. (1980). Profitability, Concentration and the Interindustry Variation in Wages, Review of Economics and Statistics, 62(2), pp. 248-253.

Rosen, Sh. (1970). Unionism and Occupational Wage Structure in the United States, International Economic Review, 11(2), pp. 269-86.

Sang C. (2005). Relationship between human resources management practices and perception of organizational Taiwan performance, roles of management style, social capital, and culture: Comparison between manufacturing firms in Cambodia and Taiwan. Taiwan: National Cheng Kung University. In Ekwoaba O. J., Ikeije U. U., Ufoma N. (2015) The Impact of Recruitment and Selection Criteria on Organizational Performance. Global Journal of Human Resources Management, Vol. 3, No. 2, pp. 23.

Scheetz, P. (1996). Employment Research Institute, Michigan State University. In A. Sherman, G. Bohlander, \& S. Snell (Eds), Managing Human Resources, South-Western College Publishing 1998, Ohio, USA, p. 146.

Sherman, A., Bohlander, G., \& Snell, S. (1998). Managing Human Resources, eleventh edn, SouthWestern College Publishing, Ohio, USA, p. 137-351.

Stigler, G.J. (1962). Information in the Labor Market. In J.M Barron, D.A. Black, \& M.A Loewenstein, Employer Size: The Implications for Search, Training, Capital Investment, Starting Wages, and Wage Growth 1987, Journal of Labor Economics, 5(1), p. 77.

Ulrich, D. (1997). Human Resource Champions: The Next Agenda for Adding Value and Delivering Results. In A.E. Wellbourne, T. M., \& Andrews, A. O. (1996). Predicting the Performance of initial Public Offerings: Should Human Resources Management Be in the Equation?, Academy of Management Journal, 39(4), pp. 891-919.

Web sources

http://aab.al/rreth-nesh/statistika/te-dhena/

http://www.bls.gov/oco/ocos001.htm

http://encyclopedia.laborlawtalk.com/Training 
https://hundred5.com/blog/cost-of-hiring-an-employee

http://www.investordictionary.com/definition/Wage.aspx, 